\title{
SALAOJITUSKOETOIMINNASTA SUOMESSA
}

\author{
TANeli JuUsela \\ Maataloushallituksen vesiteknillinen tutkimustoimisto, Helsinki \\ Saapunut 18. 5. 1953.
}

Maataloushallituksen vesiteknillinen tutkimustoimisto järjestää parhaillaan maatalousministeriön toimeksiannosta koko maan käsittävää ojituskoetoimintaa. Työn keskeneräisyydestä huolimatta on katsottu jo nyt olevan syytä selostaa eräitä sen järjestelyyn vaikuttavia peruskysymyksiä sekä koetoiminnan edistymistä.

\section{Salaojituskotoiminnan perusteet}

Salaojituksen yleisyys. Vuoden 1950 maatalouslaskennan mukaan on Suomessa yli 2 ha peltoa käsittävillä tiloilla salaojitettu kaikkiaan n. 124000 ha eli $5.4 \%$ peltoalasta. Tästä on $50 \%$ tiiliputkiojitusta, $15 \%$ lautalaatikko- tai puuputkiojitusta ja n. $35 \%$ ns. muuta salaojitusta, joka suurimmalta osaltaan on risuriukuojitusta (9). Yleisintä on salaojitus Uudenmaanläänissä, jossa pelloista on salaojitettuna $13.7 \%$, ja Ahvenanmaalla, jossa \%-luku on 11.8. Muissa lääneissä on salaojituksen osuus alle $8 \%$ (taulukko 1). Kun arviolta vain n. $10 \%$ peltoalasta viljellään nykyisin ojattomana, on avo-ojitettujen viljelysten ala kaikkiaan lähes 2 milj. hehtaaria ja avo-ojien yhteenlaskettu pituus vähintään 1.6 milj. kilometriä, mikä vastaa 4-kertaista matkaa maasta kuuhun. Salaojituksen tarpeessa ja myös taloudellisesti kannattavasti salaojitettavissa on arvioitu olevan n. 1400000 ha. Ruotsissa on viljelyksistä kaikkiaan salaojitettu n. $29 \%$, mutta tärkeimmillä viljelysalueilla etelä- ja keski-Ruotsissa on salaojitusmäärä jopa $60-80 \%$ peltoalasta, jäljellä olevan osan ollessa yleensä ojatonta.

Koneiden käytön jatkuva lisääntyminen peltoviljelystöissä on aiheuttanut sen, että nykyisin on entistä tärkeämpää selvittää, millä tavoin avo-ojien aiheuttamat haitat olisivat taloudellisesti edullisimmin poistettavissa. Jos tämä olisi pakko suorittaa tavanomaisia salaojitusmenetelmiä käyttäen, kestäisi työn suoritus nykyisellä vauhdillaan ainakin 200 vuotta ja maksaisi nykyisen hintatason mukaan laskettuna yli 100 miljardia markkaa. Jos taasen tavoitteeksi asetettaisiin esim. Ruotsin tämänhetkisen salaojitustason saavuttaminen 20 vuoden kuluessa, olisi tänä aikana salaojitettava kaikkiaan n. 540000 ha eli 27000 ha vuodessa. Määrä on noin neljä kertaa viimeisten kolmen vuoden salaojitustulosten keskiarvoa suurempi ja edel- 
Taulukko 1. Salaojitustavat lääneittäin vuoden 1950 maatalouslaskennan mukaan.

Table 1. Deep drainage methods in the various provinces according to the agricultural census of the year 1950 .

\begin{tabular}{|c|c|c|c|c|c|c|}
\hline \multirow{2}{*}{$\begin{array}{c}\text { Lääni } \\
\text { Province }\end{array}$} & & $\begin{array}{c}\text { Tiiliputki- } \\
\text { ojitus }\end{array}$ & $\begin{array}{c}\text { Lautalaatikko- } \\
\text { ja puuputki- } \\
\text { ojitus }\end{array}$ & Muu & Yhteensä & \multirow{2}{*}{$\begin{array}{l}\text { Salaojitettu } \\
\text { peltoalasta } \\
\text { Of the agri- } \\
\text { cultural } \\
\text { area is deep } \\
\text { drained } \%\end{array}$} \\
\hline & & $\begin{array}{c}\text { Tile } \\
\text { drainage } \\
\text { ha }\end{array}$ & $\begin{array}{c}\text { Nailed wooden } \\
\text { case and bored } \\
\text { wooden pipe } \\
\text { drainage } \\
\text { ha }\end{array}$ & $\begin{array}{c}\text { Other } \\
\text { methods } \\
\text { ha }\end{array}$ & Total & \\
\hline Uudenmaan, & $\mathrm{U}$ & 12508 & 5078 & 18109 & 35695 & 13.7 \\
\hline Turun ja Porin, & $\mathrm{T}$ & 23846 & 3915 & 7761 & 35522 & 7.6 \\
\hline Ahvenanmaa, & $\mathrm{A}$ & 139 & 290 & 4495 & 4924 & 11.8 \\
\hline Hämeen, & $\mathrm{H}$ & 11077 & 2185 & 2552 & 15814 & 5.3 \\
\hline Kymen, & Ky & 2011 & 795 & 1860 & 4666 & 4.0 \\
\hline Mikkelin, & M & 743 & 666 & 3356 & 4765 & 4.0 \\
\hline Kuopion, & $\mathrm{Ku}$ & 666 & 397 & 1567 & 2630 & 2.0 \\
\hline Vaasan, & $\mathrm{V}$ & 9853 & 5222 & 3842 & 18917 & 7.8 \\
\hline Oulun, & $\mathrm{O}$ & 383 & 248 & 168 & 799 & 0.2 \\
\hline Lapin, & $\mathrm{L}$ & 11 & 71 & 42 & 124 & 0.1 \\
\hline
\end{tabular}

lyttäisi vuosittain tarkoitukseen investoitavan n. 2 miljardia markkaa. Salaojituslain mukainen valtion osuus tästä olisi palkkioina n. 420 milj. markkaa ja lainoina 225 milj. markkaa eli yhteensä 665 milj. markkaa vuodessa. Niin edullista kuin salaojitus onkin, ei tällaisen ohjelman toteuttaminen nykyisiä menettelytapoja käyttäen liene maataloutemme kantokyvyn rajoissa.

Salaojien syvyys ja etäisyys. Salaojitus on kallista ja Suomessa yleensä kalliimpaa kuin monissa muissa sitä käyttävissä maissa. Tämä ei johdu yksinomaan maaperän ja ilmaston erilaisuudesta tai korkeasta hinta- ja palkkatasosta, vaan osaltaan myös salaojituksemme erikoisuuksista.

Salaojitusyhdistys on jatkuvasti suunnitellut ja paaluttanut miltei kaikki sellaiset salaojitustyöt, joita varten on myönnetty valtion palkkiota tai lainaa. Käytännössä tämä merkitsee sitä, että yli $90 \%$ salaojituksista on suoritettu ja edelleenkin suoritetaan Salaojitusyhdistyksen ohjeiden mukaisesti. Viime aikoihin asti voimassa olleiden määräysten (15) mukaan on salaojien syvyyden ollut oltava kivennäismailla: e t e lä-S u o mess a 120 cm, keski-Suomessa $130 \mathrm{~cm}$ ja po h joisS u o m es s a $140 \mathrm{~cm}$ (suunnilleen siltä korkeudelta lähtien missä vuoden keskilämpötila on alhaisempi kuin $+1^{\circ} \mathrm{C}$ ). Urpasavi- ja liejumailla on sallittu käyttää $20 \mathrm{~cm}$ pienempää syvyyttä. Painuneilla, jo viljelyksessä olleilla soilla on salaojasyvyys kaikkialla maassa ollut $120 \mathrm{~cm}$ ja puutarhaojituksissa $140 \mathrm{~cm}$. Edellä tarkoitetut syvyydet on laskettu putken päältä maanpintaan, joten salaojien kaivusyvyys on näitä putken ulkoläpimitan verran suurempi. Syvemmän salaojituksen käyttöä pohjoisempana perustellaan routavaaralla. Edellä selostettuja määräyksiä on v. 


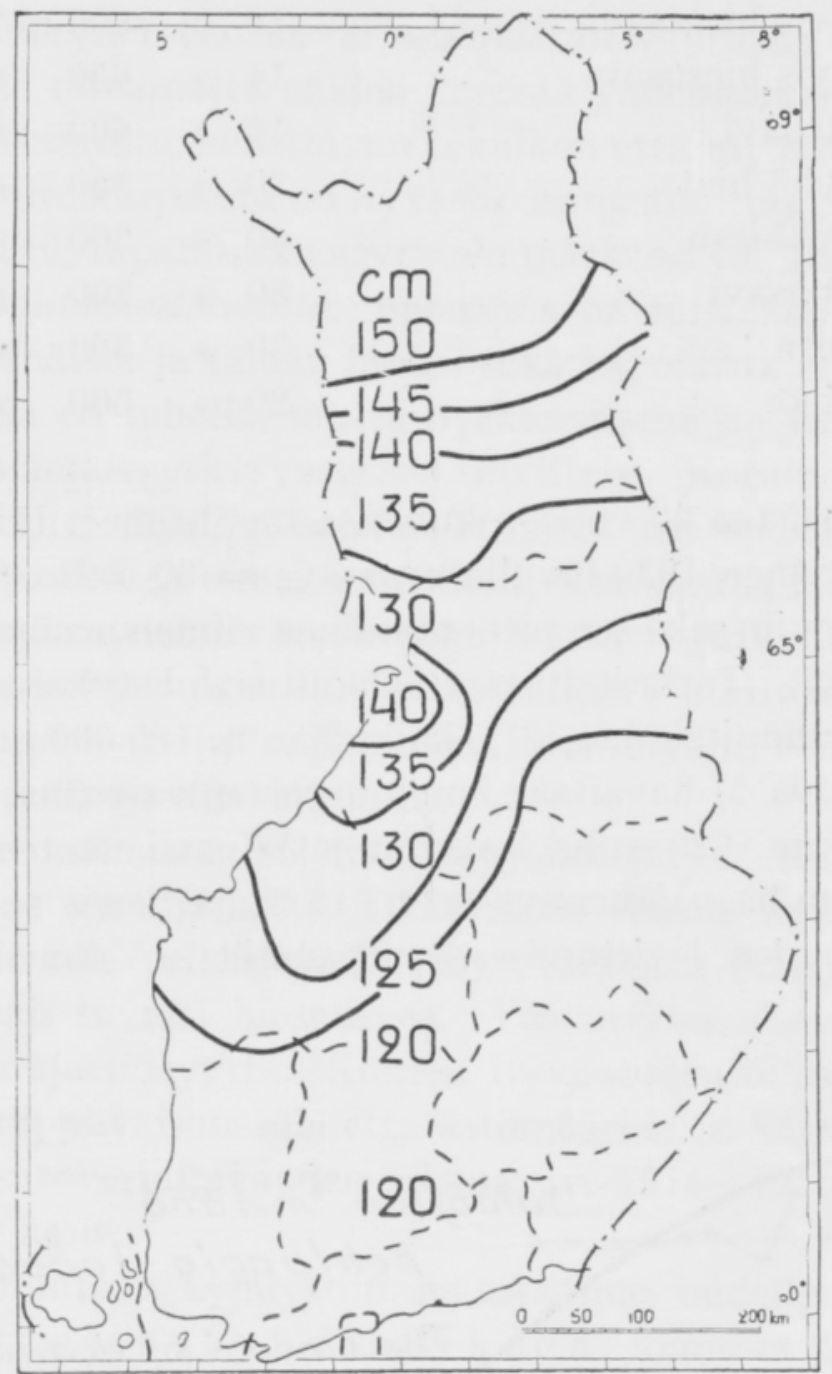

Kuva 1. Salaojien määräsyvyydet eri osissa Suomea tiiviillä kivennäismailla vuonna 1951 annettujen ohjeiden mukaan.

Figure 1. Drain depths in different parts of Finland on mineral soil according to the instructions given in 1951.

1951 jossain määrin muutettu (16). Muutos kohdistuu lähinnä keski- ja pohjoisSuomeen, jossa ojien syvyys on nyt saatettu riippuvaiseksı lumen keskivahvuudesta (kuva 1). Menettelytapa on jossain määrin epäjohdonmukainen, sillä routa saattaa esim. vähälumisena talvena tunkeutua huomattavasti syvemmälle kuin keskimääräisten lumisuhteiden vallitessa. Mainittakoon tässä yhteydessä, että esim. Ruotsissa käytetään sekä pohjois- että eteläosissa maata suunnilleen samoja syvyyksiä salaojitusten yleensä ollessa siellä $30-50 \mathrm{~cm}$ matalampia kuin vastaavissa olosuhteissa Suomessa (7).

Salaojien suuremmasta syvyydestä huolimatta käytetään Suomessa eri maalajeilla kutakuinkin samoja salaojien etäisyyksiä kuin Ruotsissa (2). Salaojien etäisyydet ja ojamäärä hehtaaria kohden laskettuna ovat etelä-Suomen olosuhteissa tärkeimmillä maalajeilla nykyisin seuraavat (9): 


\begin{tabular}{|c|c|c|c|c|}
\hline tiivis hietasavi & $\ldots \ldots$ & 18 & $\mathrm{~m}$ & 600 \\
\hline tiivis hiesusavi & $\ldots \ldots \ldots$ & 14 & $"$ & 650 \\
\hline aitosavi $\quad \ldots$. & & 16 & $"$ & 600 \\
\hline jyhä hieta . . & & 30 & $"$ & 350 \\
\hline rpahiesu .... & & 40 & $"$ & 300 \\
\hline pasavi .... & & 80 & $"$ & 200 \\
\hline & & 30 & $"$ & 360 \\
\hline$\ldots \ldots$ & & 20 & $"$ & 500 \\
\hline
\end{tabular}

Ojaetäisyydessä viimeisten 20 vuoden kuluessa tapahtuneet tärkeimmät muutokset ovat olleet sen lisääminen 1930-luvulla urpasavessa $30 \mathrm{~m}$ :sta $80 \mathrm{~m}$ :iin ja urpasavihiesussa $20 \mathrm{~m}$ :sta $40 \mathrm{~m}$ :iin sekä sen pienentäminen viime vuosina rahkasoilla $30 \mathrm{~m}$ :sta 20 m:iin (13, 14 ja 17). Tarkasteltaessa Salaojitusyhdistyksen vuosina $1930-1951$ laatimien salaojitussuunnitelmien (21), kaikkiaan n. 185000 ha, perusteella ojaetäisyyden kehitystä (kuva 2) havaitaan em. muutosten vaikutus. Niinpä on ojamäärä oltuaan v. 1932 keskim. $620 \mathrm{~m} /$ ha laskenut jatkuvasti vuoteen 1941 saakka ollen tällöin keskim. $510 \mathrm{~m} / \mathrm{ha}$. Vähennys on n. $18 \%$ ja lienee se suurimmaksi osaksi aiheutunut ojaetäisyyden levittämisestä urpamailla. Verrattaessa ojitustiheyden

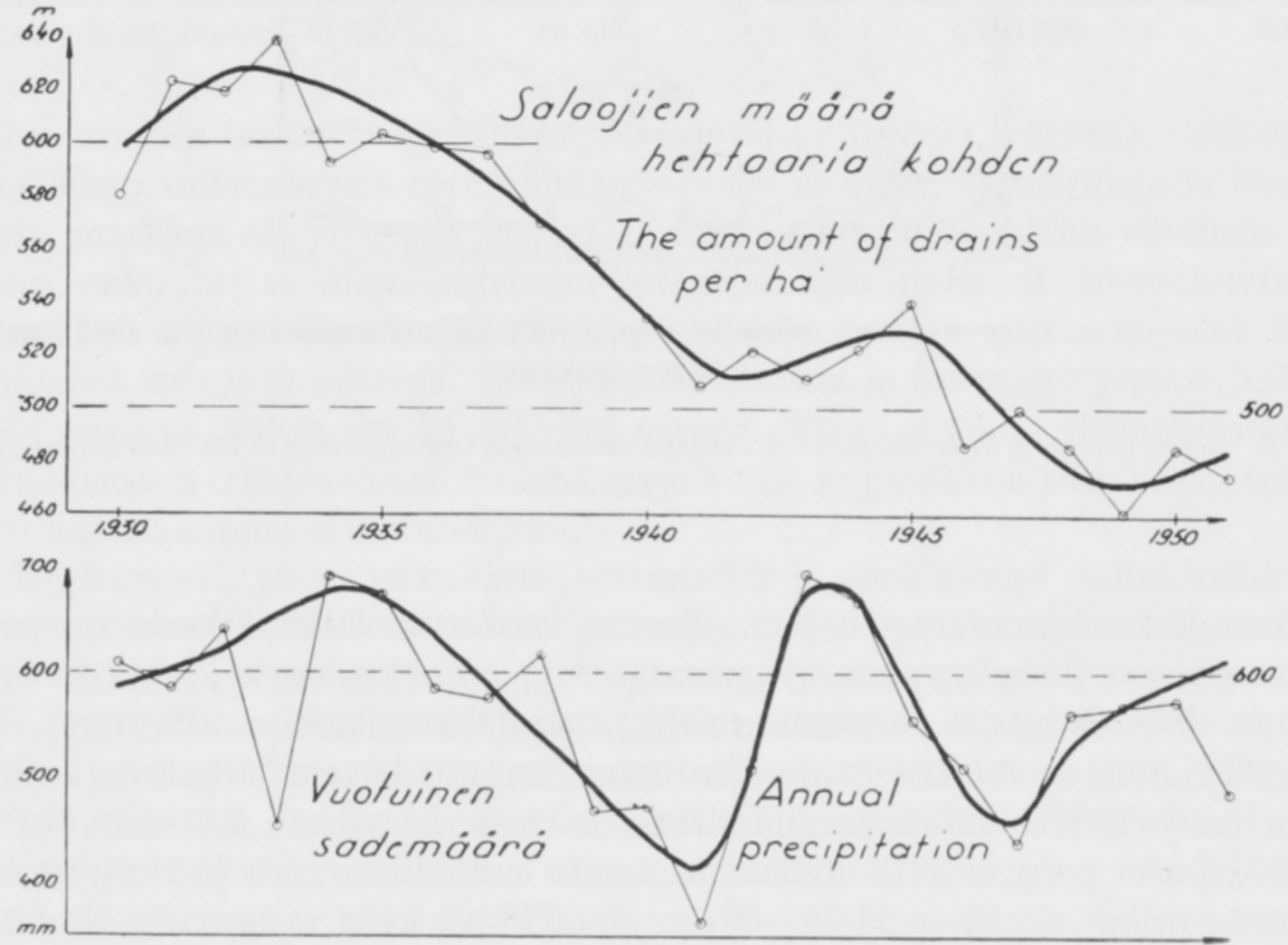

Kuva 2. Salaojien etäisyyden muutokset vuosina 1930-1951 Salaojitusyhdistyksen laatimien suunnitelmien perusteella.

Figure 2. Changes in drain distances in the years 1930-51 on the basis of the plans made by the "Deepdrainage Association." 
muutosta kuvaavaa käyrää vuotuisen sademäärän vaihtelua osoittavaan käyrään ei kuitenkaan voi olla toteamatta näiden ilmeistä yhdenmukaisuutta. Luonnollista onkin, että sekä tutkimusta suorittavan teknikon että myös viljelijän oma käsitys jonkin peltolohkon ojitustarpeesta on hyvästäkin maalajituntemuksesta huolimatta riippuvainen myös siitä, tapahtuuko arvostelu märkänä vai kuivana aikana.

Aikaisempi salaojituskoetoiminta. Suomessa on tähänastinen salaojituskoetoiminta ollut varsin vähäistä ja tämän lisäksi sekä hajanaista että yksipuolista. Sitä on harrastettu usealla eri taholla, mutta pyrkimyksenä on vuoteen 1947 asti ollut miltei yksinomaan ojaetäisyyskysymyksen selvittely. Koealueet ovat olleet pieniä ja maasto yleensä miltei täysin tasaista. Tutkittavien ojaetäisyyksien valinnassa on vain harvoissa tapauksissa onnistuttu sikäli, että usealla maalajilla käytännössä nykyisin yleiset ojaetäisyydet eivät ole joko lainkaan tutkimuksiin sisältyneet tai ovat samansuuruisia kuin kapein tai levein tutkittu etäisyys. Lisäksi ovat koealueiden vähälukuisuuden vuoksi niiden valinnassa sattuneet virheellisyydet aiheuttaneet merkittäviä aukkoja tutkimuksiin.

Tiettävästi ensimmäinen salaojien etäisyyskoe järjestettiin vuonna 1908 prof. I. A. H a ll a k orven toimesta Tikkurilaan eräälle nykyisin Maatalouskoelaitoksen hallussa olevalle peltolohkolle (22). Salaojien etäisyydet olivat 8, 10.5, 13 ja $15 \mathrm{~m}$ ja maalaji tiivistä hiesusavea. Vastaavissa olosuhteissa käytettäisiin nykyisin 14-15 m:n ojaetäisyyttä. Kokeen 13-vuotisten tulosten perusteella ei ole todettavissa selvää riippuvaisuussuhdetta satomäärien ja käytettyjen ojaetäisyyksien välillä, vaikka satovertailukauden aikana vv. 1914 -1926 sattui sekä erittäin sateisia että kuivia kesiä.

Salaojituskoetoimintaan ryhdyttiin maassamme uudelleen vasta 1920 -luvun jälkipuoliskolla S a la o j i t u s y h dist y k se n toimesta (21). Viimeinen tähän koesuunnitelmaan sisältyvästä seitsemästä, eri maalajeille sijoitetusta koekentästä salaojitettiin vuonna 1931. Koekenttien suuruus oli $1.5-2$ ha ja oli niillä salaojien etäisyyskysymyksen selvittämiseksi suoritettu salaojitus neljää tai viittä toisistaan poikkeavaa ojaetäisyyttä käyttäen (taulukko 2). Ojien syvyys oli kaikissa kokeissa sama, n. 120-130 cm putken päältä mitattuna.

Verrattaessa kokeissa, eri maalajeilla käytettyjä salaojien etäisyyksiä, käytännössä KESON (13 ja 17) mukaan vuosina 1932 ja 1952 samoilla maalajeilla käytettyihin ojaetäisyyksiin, havaitaan, että koejärjestely on ojaetäisyyksien valintaan nähden ollut tarkoituksenmukainen vain aitosavi-, tiivishiesusavi- ja mutasuokokeessa. Lisäksi on tiiviillä hiesusavella oleva koealue osoittautunut maalajieroavaisuuksien vuoksi epäonnistuneeksi ja mutasuokokeessa ojituksen toiminta on ollut rautasaostumisen vuoksi jatkuvasti epätyydyttävä. Edellä esitetty lienee osaltaan vaikuttanut siihen, ettei tämän koetoiminnan tuloksia ole, eräitä erillisiä havaintoja lukuunottamatta, saatettu julkisuuteen, vaikka havaintojen suoritus koealueilla on lopetettu jo 1930-luvun lopulla eli 10-15 vuotta sitten. On kuitenkin otaksuttavaa, että myös näistä kokeista saadut tulokset ovat vaikuttaneet meillä salaojituksessa nykyisin käytettyjen ja edellä selostettujen ojaetäisyyksien valintaan.

Salaojitusyhdistyksen toimesta on viime vuosina järjestetty turvemaan ojituskokeita pohjois-Suomessa Apukan koeasemalla lähellä Rovaniemeä ja Kolarissa 
Taulukko 2. Salaojitusyhdistyksen ojituskoekentät.

Table 2. Experimental drainage field of the "Deep-drainage Association".

\begin{tabular}{|c|c|c|c|c|c|}
\hline \multicolumn{3}{|c|}{$\begin{array}{l}\text { Salaojituskoekentän } \\
\text { Experiment field }\end{array}$} & \multicolumn{3}{|c|}{$\begin{array}{l}\text { Salaojaetäisyys }(\mathrm{m}) \\
\text { Distance of drains }\end{array}$} \\
\hline \multirow{2}{*}{$\begin{array}{l}\text { ojitus- } \\
\text { vuosi } \\
\text { year of } \\
\text { drainage }\end{array}$} & \multirow{2}{*}{$\begin{array}{l}\text { sijainti } \\
\text { location }\end{array}$} & \multirow{2}{*}{$\begin{array}{l}\text { maalaji } \\
\text { soil type }\end{array}$} & \multirow{2}{*}{$\begin{array}{l}\text { kokeessa } \\
\text { in experiment }\end{array}$} & \multicolumn{2}{|c|}{$\begin{array}{l}\text { käytännössä } \\
\text { in practice }\end{array}$} \\
\hline & & & & 1932 & 1952 \\
\hline 1926 & Kangasala, Vääksy & $\begin{array}{l}\text { hiesusavi } \\
\text { silt clay }\end{array}$ & $10-12.5-15-17.5-20$ & 14 & 14 \\
\hline 1925 & Jokioinen, Kartanot & $\begin{array}{l}\text { aitosavi } \\
\text { heavy clay }\end{array}$ & $12.5-15-17.5-20-22.5$ & 16 & 16 \\
\hline 1927 & Köyliö, Kepola & $\begin{array}{l}\text { hiekka, sand } \\
\text { hieta, fine sand }\end{array}$ & $15-20-25-30$ & 25 & 30 \\
\hline 1926 & Kauhava, Jokiniemi & $\begin{array}{l}\text { urpahiesu } \\
\text { mud silt }\end{array}$ & $13-17-21-25$ & 22 & 40 \\
\hline 1925 & Porvoo, Kiiala & $\begin{array}{l}\text { urpasavi } \\
\text { mud clay }\end{array}$ & $15-20-25-30-35$ & 35 & 80 \\
\hline 1931 & Tammela, Mustiala & $\begin{array}{l}\text { rahkasuo } \\
\text { bog peat soil }\end{array}$ & $21.6-33.8-44.5-56.3$ & 30 & 20 \\
\hline 1930 & Revonlahti, Ruukki & $\begin{array}{l}\text { mutasuo } \\
\text { swamp peat soil }\end{array}$ & $17-24-31-38$ & 40 & 30 \\
\hline
\end{tabular}

Teuravuoman tilalla n. $150 \mathrm{~km}$ Torniosta pohjoiseen. Tulkoon tässä yhteydessä mainituksi, että yksinomaan Teuravuoman ojituskokeisiin on tähän mennessä käytetty valtion varoja lähes kaksi kertaa se määrä, minkä maatalousministeriön asettama salaojitusasiantuntijatoimikunta on arvioinut tarvittavan koko maan käsittävän salaojituskoetoiminnan perustamisvaiheen toteuttamiseen.

Turvemailla on ojitustarvetta selvitetty myös S u o vil jel ys y h dis t y ks e n toimesta. Mutasuon salaojien etäisyyskoe perustettiin v. 1931 Karjalan koeasemalla Tohmajärvellä. Salaojien alkuperäinen syvyys oli keskimäärin $120 \mathrm{~cm}$, ja etäisyydet $10,20,30$ ja $40 \mathrm{~m}$. Tämän kokeen rinnalla on ollut käynnissä jo vuonna 1923 perustettu avo-ojituskoe, jossa sarkaleveydet ovat 10, 20 ja $30 \mathrm{~m}$ ja ojien syvyydet $30,50,70$ ja $90 \mathrm{~cm}$ (18 ja 19). Avo-ojituskokeen tuloksista mainittakoon, että kuivatustarve osoittautui alkuvuosina raivauksen jälkeen suuremmaksi kuin myöhemmässä vaiheessa, jolloin turvekerros oli jo ennättänyt tiivistyä. Salaojituskokeen tulokset ovat samansuuntaisia. Aluksi saatiin paras satotulos $30 \mathrm{~m}: \mathrm{n}$ imuojaetäisyyttä käytettäessä, mutta myöhemmin, kun ojituksen suorittamisesta oli jo kulunut kymmenkunta vuotta, osoittautui 40 m:n etäisyys edullisimmaksi.

Ma a taloushallituksen vesiteknillisen tutkimustoi$\mathrm{m}$ i s t o n aloitteesta perustettiin Jokioisiin raivaustöiden yhteydessä vuonna 1947 sekä sala- että avo-ojituskoe ja purkautumishavaintoalue. Salaojituskokeessa ovat ojien etäisyydet 12,18 ja $24 \mathrm{~m}$ ja syvyydet 60,90 ja $120 \mathrm{~cm}$. Lisäksi on osa alueesta roudan vaikutusten selvittämistä varten salaojitettu vain $30 \mathrm{~cm}$ :n syvyyttä käyt- 
täen. Avo-ojituskokeeseen sisältyy sekä pitkittäis- että poikittaisojituskoe. Sarkaleveydet ovat 12,18 ja $24 \mathrm{~m}$ ja ojien syvyydet 30 ja $60 \mathrm{~cm}$. Purkautumishavaintoalue on perustettu mitoitusperusteiden selvittelyä varten (6) ja käsittää kaikkiaan kahdeksan noin 2.5 ha:n suuruista piiriojilla rajoitettua koelohkoa. Näistä on kaksi sarkaojitettu, kaksi ojatonta, yksi salaojitettu ja kolme metsänkasvussa. Edellä mainitut kokeet ovat yhteiseltä pinta-alaltaan n. 20 ha.

Jokioisten salaojituskokeiden tulokset, jotka myöhemmässä vaiheessa tullaan yksityiskohtaisina saattamaan julkisuuteen, ovat eräiltä osiltaan olleet varsin yllättäviä. Nïnpä on ojattomilta 2.5 ha:n suuruisilta purkautumiskoelohkoilta useina vuosina saatu joko samansuuruinen tai suurempi sato kuin vastaavilta avo- tai salaojitetuilta lohkoilta. Ojien etäisyyden vaikutus sadon määrään on myös eri vuosina ollut varsin erilainen ja jopa samanakin vuonna syvyyskokeissa sekava. Parhaan tuloksen on useimpina vuosina antanut $90 \mathrm{~cm}$ :n syvyinen ojitus, mutta satoerot ovat tässä samoin kuin etäisyyskokeissakin olleet yleensä koevirheiden suuruusluokkaa.

Edellä esitetty osoittanee riittävän selvästi, että S u o m e s s a n y k y is i n eri maalajeilla käytettyjä salaojien etäisyyksiä ja -syvyyksiä ei voida perustella kotimaisen koetoiminnan t u loksilla. Menettelytavat pohjautunevatkin osaksi ulkomailla 1920-luvulla vallinneeseen käytäntöön ja osaksi sekä viljelijöiden itsensä että salaojitusasioista huolehtineiden ammattimiesten käsitykseen viljelysten yleisestä kuivatustarpeesta.

Viime aikaiset havainnot ovat osoittaneet, että ojitustavalla, olipa sitten kysymyksessä avo- tai salaojitus, on ollut yllättävän vähän vaikutusta satotulokseen, kunhan vain niska- ja valtaojat ovat olleet kunnossa ja vesivakoja käytetty riittävästi. Se, että ojitustarve näin ollen vaikuttaa odotettua vähäisemmältä, saattaa osaltaan johtua nykyaikaisen muokkauskerroksen kuivatuksellisesta ja kosteuseroja tasoittavasta vaikutuksesta, sillä kyntösyvyys on viimeisten $20-30$ vuoden aikana miltei kaksinkertaistunut ja muokkaus tullut traktorivetoisten muokkausvälineiden käytön yleistymisen vuoksi entistä tehokkaammaksi. Myös apilavaltaisten nurmien yleistymisellä viime vuosikymmeninä on apilan syväjuurisuuden vuoksi saattanut olla merkitystä jäykkien savimaiden fysikaalisen rakenteen parantajana. Lisäksi on otettava huomioon kevätviljojen osuuden lisääntymisen viljelysten yleistä kuivatustarvetta vähentävä vaikutus.

R u o t s is s a vuodesta 1947 lähtien järjestetyn varsin laajan salaojituskoetoiminnan tähänastiset tulokset varmentavat omalta osaltaan sekä sikäläisen aikaisemman suppean koetoiminnan tuloksia että myös edellä esitettyä (5). Koealueilta, joilla salaojien syvyys oli $60-75 \mathrm{~cm}$, saatiin siellä vuosina 1949-1951 keskimäärin vain $2 \%$ pienempi sato kuin niiltä alueilta, joilla salaojat olivat $100-120 \mathrm{~cm}$ syviä. Lisäksi oli noin kolmasosa tapauksista sellaisia, joissa matalaan ojitetun alueen sato oli joko sama tai suurempi kuin syvempään ojitetulta alueelta saatu sato. Salaojien etäisyyden selvittelyä varten perustetuista koealueista, joita kaikkiaan oli $70 \mathrm{kpl}$. oli vain kolme sellaista, joilla vuosien 1949-1951 satovertailun perusteella olisi ollut taloudellisesti edullisempaa käyttää nykyistä kapeampaa ojaetäisyyttä. Niistä kokeista taasen, joissa ojaetäisyys oli nykyisin käytettyyn verrattuna kaksinkertainen, oli $60 \%$ sellaisia, joissa ojaetäisyyttä olisi vieläkin ollut syytä leventää. 


\section{Salaojituskoetoiminnan keskittäminen}

Koetoiminnan laajuns. Maatalousministeriö asetti kevättalvella 1951 erityisen salaojitusasiantuntijatoimikunnan laatimaan esitystä salaojitusmenetelmien kehittämistä tarkoittavan koe- ja tutkimustoiminnan järjestämiseksi koko maassa. Toimikunnan puheenjohtajaksi määrättiin yli-ins. A. H. Schroderus maataloushallituksesta ja jäseniksi agr. Veikko Ihamuotila, tekn.tri. Taneli Juusela, prof. Pentti Kaitera, prof. Lauri Keso, maist. E. Korpela, dipl.ins. Eino W. SeppäNEn sekä prof. Otto VAlle. Sihteerinä toimii tekn.tri. Matti Wäre.

Yleispiirteinen toimintasuunnitelma vahvistettiin maatalousministeriössä 24 p:nä toukokuuta 1951 ja samalla ministeriö määräsi tekn.tri. Taneli Juuselan Maataloushallituksen vesiteknilliseen tutkimustoimistoon tätä työtä johtamaan. Tutkimusagronomina on toiminnan alusta lähtien ollut agr. ERккI PäLıккö. Kesäapulaisina kenttätöissä on lisäksi käytetty agraariylioppilaita tarpeen mukaan. Tutkimus-, paalutus- ym. tehtävissä on jouduttu jatkuvasti käyttämään apuna myös muuta työvoimaa.

Koe- ja tutkimustoiminnan rungon muodostavat neljälle valtion omistamalle tilalle perustettavat varsinaiset salaojituskoekentät ja näitä täydentävät eri osiin maata lähinnä yksityisille tiloille perustettavat erilliset salaojituskoealueet.

Tutkimusten, suunnittelun, asiakirjojen laatimisen, paalutuksen ja tarkastuksen aiheuttamiin kustannuksiin käytetään koetoimintaa varten myönnettyjä erikoisvaroja, joten nämä kustannukset eivät joudu koetilojen omistajien rasitukseksi. Varsinaisista ojitustöistä sitä vastoin vastaa viljelijä itse saaden salaojitustöistä kyseen ollen kuitenkin tavanmukaisen salaojituspalkkion ja -lainan.

Salaojituskoealueita on tarkoitus perustaa kaikkiaan 143 tilalle ja jakautuvat ne tarkoituksensa mukaan seuraavasti:

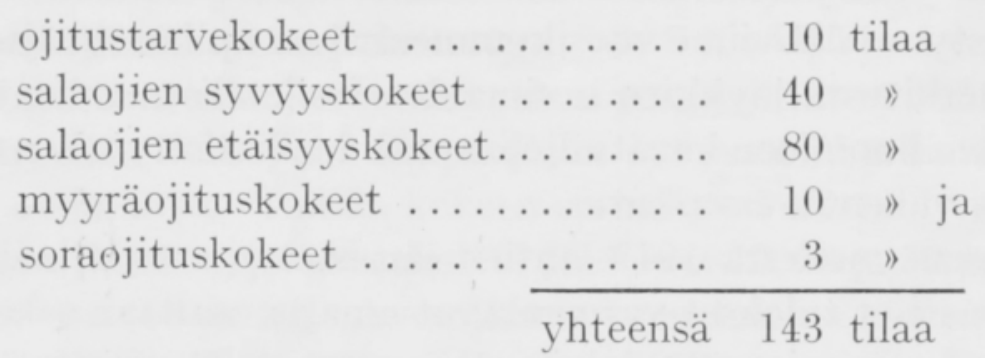

Määrärahoja nyt kysymyksessä olevan koe- ja tutkimustoiminnan perustamisvaihetta varten on saatu maatalousministeriöltä maatalouden tuotantokustannusten tasoittamiseen ja tuotannon edistämiseen tarkoitetuista varoista seuraavasti:

$$
\begin{array}{rrr}
1951 \ldots \ldots & 4.500 .000 \quad \mathrm{mk} \\
1952 \ldots \ldots & 10.350 .000 \quad \text { " ja } \\
1953 \ldots \ldots & 5.623 .000 \quad \text { " eli } \\
\hline \text { yhteensä } & 20.473 .000 \mathrm{mk}
\end{array}
$$


Salaojituskoekenttien ja salaojituskoealueiden varsinaiset perustamistyöt pyritään saamaan pääosiltaan valmiiksi vuoden 1953 aikana. Koealueiden hoitoon ja tutkimusaineiston käsittelyyn vuosittain jatkuvasti tarvittavat varat on tarkoitus ottaa huomioon Maataloushallituksen vesiteknillisen tutkimustoimiston kunkin vuoden tulo- ja menoarvioesityksen yhteydessä.

Ojituskoetoiminnan tarkoituksena on sekä taloudellisesti että teknillisesti edullisimpien menettelytapojen etsiminen ja kehittäminen eri olosuhteita varten. Taloudellisessa selvittelyssä joudutaan tehokkaamman kuivatuksen aiheuttamaa ojituksen vuotuiskustannuksen kasvua vertaamaan vastaavaan sadon raha-arvon muutokseen. Ojitustapa, jota käyttäen saadaan paras satotulos, saattaa vertailun perusteella osoittautua taloudellisesti kannattamattomaksi. Toisaalta saattaa ojitustavan vaikutus esim. kevätkuivumisen tasaisuuteen, maan muokkauskuntoon ja sen kantavuuteen olla siksi merkittävä, että sen johdosta on syytä poiketa taloudellisen vertailun perusteella tehdyistä johtopäätöksistä.

Kokonaisuuden kannalta ei ole kysymys yksinomaan salaojituksesta, vaan lähinnä siitä, miten avo-ojien aiheuttamista haitoista parhaiten päästäisiin. O j ituskoetoiminnan tehtävänä on selvittää milloin ja minkälaista salaojitusta tähän tarvitaan ja missä määrin peltoja voidaan viljelläjoko kokonaan ilman ojia tai nykyistä harvempaa avo-ojitusta käyttäen.

Ojitustarpeen selvittely. Kuten edellä on jo mainittu arvioidaan pelloistamme viljeltävän nykyisin n. $10 \%$ ilman ojitusta. Useat viime aikoina suoritetut kokeet ja käytännön kokemus ovat osoittaneet, että tätä määrää voidaan haitatta melkoisesti lisätä. Koetoiminnan tehtävänä on selvittää, minkälaisissa olosuhteissa näin voidaan menetellä. Lähinnä tullevat tällöin kysymykseen rinnemaat, joilla avoojien kuivatuksellinen vaikutus on niiden epäedullisen suunnan vuoksi nykyisinkin melko vähäinen. On selvitettävä, mikä merkitys on niskaojien suuruudella ja milloin avo-ojat voidaan kokonaan poistaa ja milloin on tyydyttävä vähempään, esim. kaksin- tai kolminkertaistamaan nykyinen sarkaleveys kyntämällä väliojat umpeen.

Vuosikymmenien ja eräissä tapauksissa vuosisatojenkin kuluessa syntynyt kupera sarkamuoto aiheuttaa sen, että vesillä on taipumus edelleenkin ojien umpeenkynnön jälkeen keräytyä, jankon pintaa myöten valuen, entisten avo-ojien paikoille. Varsinkin tiiviillä savimailla joudutaan tämän vuoksi selvittämään, miten avo-ojia hävitettäessä olisi edullisinta menetellä. Ojien suoranainen umpeenkyntö johtanee vain harvoin toivottuun tulokseen. Entisten avo-ojien kohdalle kertyville vesille on pyrittävä säilyttämään poispääsymahdollisuus ainakin niin pitkäksi ajaksi, että tämäkin kohta on ennättänyt tiivistyä ja pellon pinta tasaantua. Minkälaisia toimenpiteitä tämä eri tapauksissa edellyttää, on tutkimuksilla selvitettävä. Oma merkityksensä on myös kyntö- ja muokkaussuunnalla sekä vesivakojen sijoituksella ja suuruudella. Avo-ojia rinnemaastossa hävitettäessä jouduttaneen myös tutkimaan sellaisen yhdistelmäojituksen käyttömahdollisuuksia, jossa peltolohkon tasaisemmassa alaosassa rinteen taitekohdasta alkaen käytetään poikittaissuuntaista salaojitusta ja yläosaa viljellään vain vesivakoja apuna käyttäen (kuva 3). Tarkoituksenmukainen ratkaisu on löydettävä sekä ylä- että alarinnetapauksia varten. 


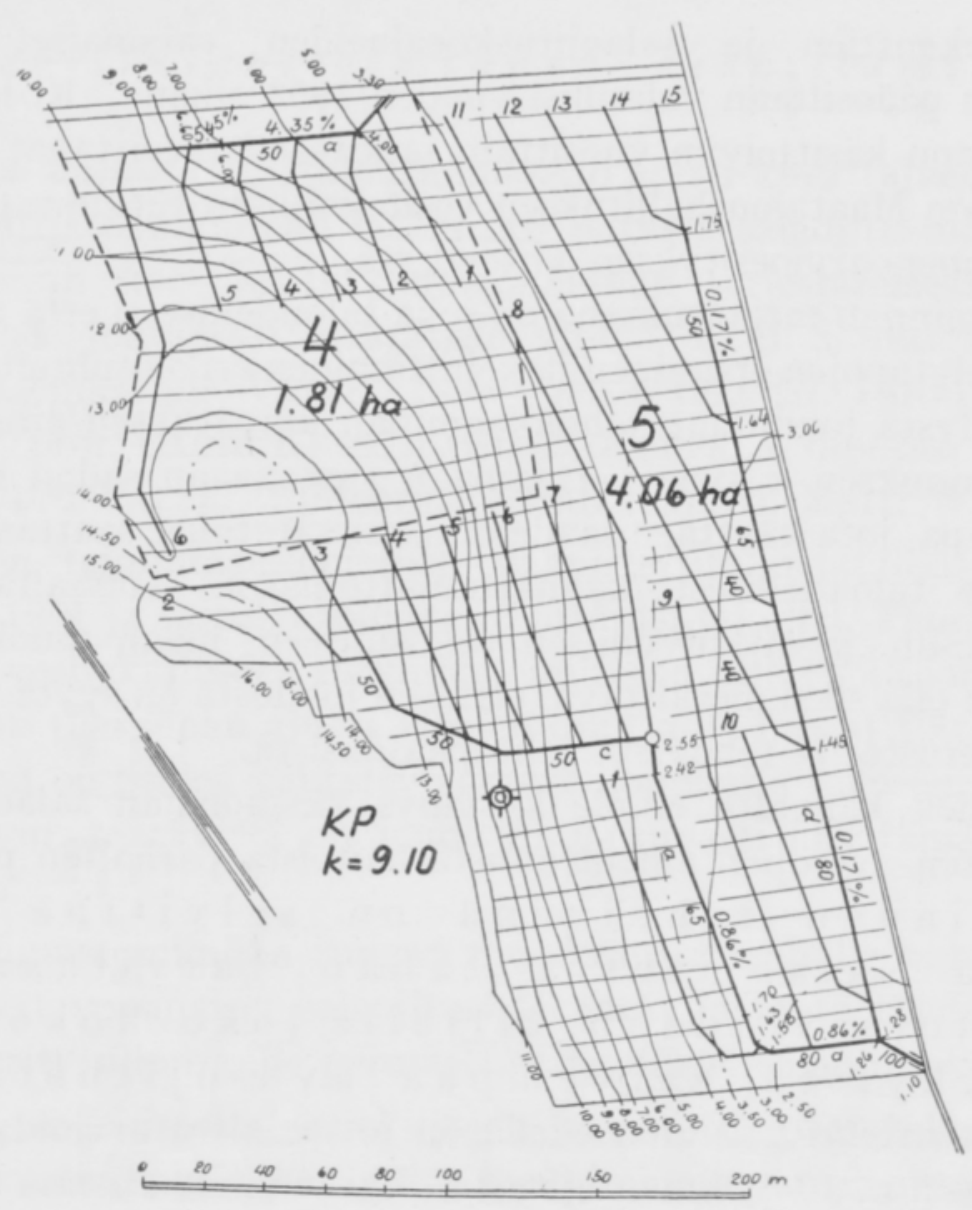

Kuva 3. Salaojituskoealue ojitustarpeen selvittelyä varten rinnemaastossa tiiviillä hiesusavimaalla.

Figure 3. Experimental deep-drainage area set up for the purpose of determining the need of drainage on slope terrain on heavy silt clay soil. The areas to be compared are drained with tile drains distance $16-20 \mathrm{~m}$. and depth $90 \mathrm{~cm}$.

Erilaisia ojitustapoja koskevat tutkimukset. Pyrittäessä löytämään nykyistä edullisempia salaojitusmenetelmiä on huomio kiintynyt siihen, että salaojitetusta peltoalasta on n. 44000 ha eli $35 \%$ maanviljelijöiden omatoimisesti, kotoisia tarvikkeita käyttäen suorittamaa ns. muuta salaojitusta (taulukko 1). Näitä ojitustöitä ei ole valtiovallan toimesta taloudellisesti tuettu eikä millään tavoin ohjattu ja valvottu. Nyt käynnissä olevan koetoiminnan yhteydessä on katsottu tarpeelliseksi selvittää olisiko näissä ojituksissa käytettyjä menettelytapoja syytä salaojituskoetoimintaa laajennettaessa edelleenkin soveltaa käytäntöön. Tämän johdosta suoritetussa tutkimuksessa (9), joka kaikkiaan käsittää n. 7300 ha tällaista muuta ojitusta, todettiin, että n. $80 \%$ siitä oli risuriukuojitusta. Kiviojitusta oli $15 \%$ ja soraojitusta ja muita erilaisia menettelytapoja käyttäen suoritettuja salaojituksia $5 \%$ tutkitusta määrästä.

Risuriukuojituksen käyttöön on harrastus ollut vilkkaimmillaan 1920-luvulla, mutta tämän ojitustavan saavuttama suosittu asema ilmenee siitä, että yli $10 \%$ kokonaismäärästä on ojitettu viimeisten viiden vuoden aikana. Koko tutkitusta määrästä oli $74 \%$ hyvässä, $22 \%$ tyydyttävässä ja vain $4 \%$ huonossa 


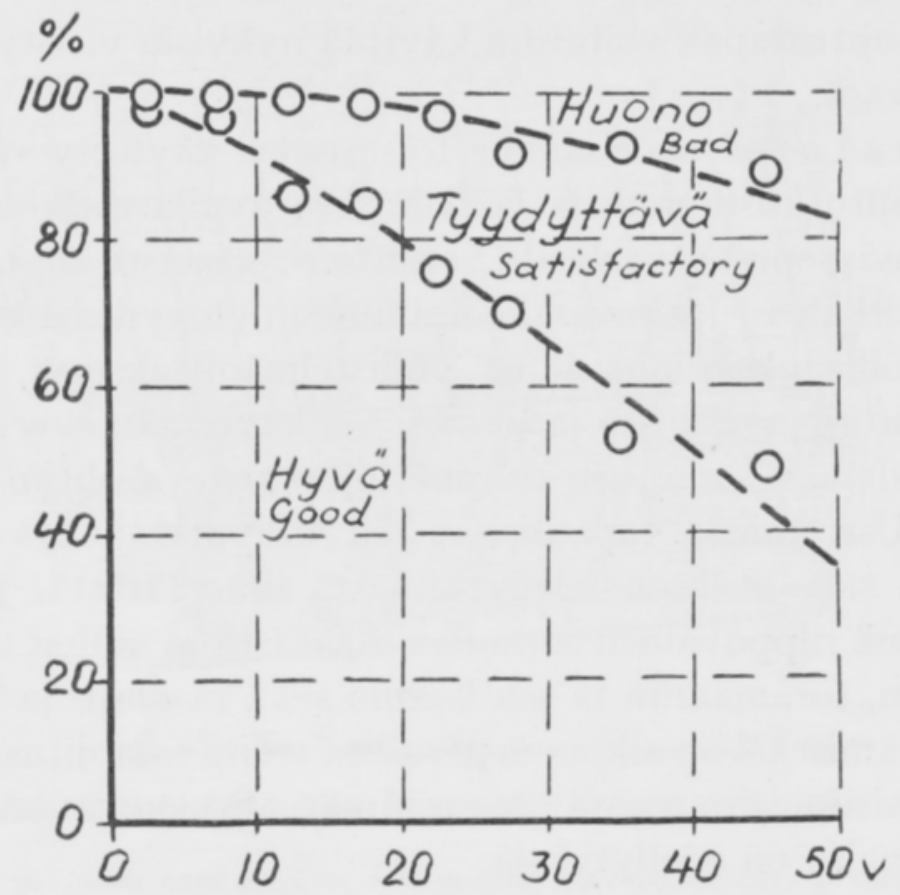

Kuva 4. Risuojituksen kunnon riippuvaisuus ojituksen iästä vuonna 1951 suoritetun tutkimuksen perusteella.

Figure 4. Dependence of the condition of brush drainage on the age of the drainage according to the investigation carried out in 1951.

kunnossa siitä huolimatta, että noin neljäs osa ojituksista oli yli 30 vuotta vanhaa. Huolellisesti tehdyt risuriukuojitukset säilyvätkin toimintakykyisinä keskimäärin ainakin 30 vuotta (kuva 4). Yleisin ja halvin tapa on tehdä risuriukuojat karsimattomista puista ja risuista ja sijoittaa ne entisiin avo-ojiin niitä syventäen. Oja on syytä kaivaa noin metrin syvyiseksi ja $25-30 \mathrm{~cm}$ leveäksi, sekä täyttää se vähintään $60-70 \mathrm{~cm}: n$ vahvuudelta riu'uilla ja risuilla, jotka ladotaan suomukseen tyvet alaspäin siten, että asettelu aloitetaan ojan yläpäästä. Täten aikaansaadun varsinaisen vedenjohtokerroksen suojana, estämään hienojakoisen maan valuminen puutäytteen rakoihin, on aina käytettävä tarpeellinen määrä joko kuusen tai katajan oksia tai olkipahnaa. Jos erilliset risuriukuojat lisäksi yhdistetään järeämpää puuainesta käyttäen tehdyillä suuremmilla kokoojaojilla ojastoiksi ja näiden laskuaukoista jatkuvasti huolehditaan, pysyy ojitus toimintakykyisenä huomattavan pitkän ajan. Risuriukuojituksen kustannukset ovat yleensä vähemmän kuin puolet tiiliputkiojituksen kustannuksista, mikäli käytetylle puutavaralle (n. $5 \mathrm{~m}^{3} 100$ ojametriä kohden) ei tarvitse laskea hintaa. Tämän ojitustavan käyttöä voidaan edelleenkin suositella suunnitelmallista salaojitusta edeltävänä ratkaisuna lähinnä sellaisille pienviljelmille, joilla on kotoista työvoimaa runsaasti käytettävissä. Mikäli ojiin tarvittavia risuja ja riukuja on helposti saatavissa eikä ajomatka ole pitkä, työn suoritus ei aiheuta ojittajalle sanottavia rahallisia menoja.

Kiviojitukseen kohdistuneen selvittelyn perusteella on tultu siihen tulokseen, ettei sillä, vaatimansa suuren työmäärän vuoksi, ole sanottavia käyttömahdollisuuksia jatkuvassa salaojitustoiminnassa. Kuitenkin on tarkoitus tutkia, 
missä määrin tätä ojitustapaa voitaisiin käyttää nykyisin yleistyneen kivenraivaustoiminnan yhteydessä.

S o r a o j it u sta on maassamme toistaiseksi käytetty varsin vähän, mutta ilmeistä on, että ojituskustannuksia voidaan sen avulla melkoisesti alentaa sellaisilla seuduilla, missä sopivan karkeata soraa on runsaasti käytettävissä, eikä ajomatka muodostu pitkäksi. Jatkuvan koetoiminnan yhteydessä tullaan selvittämään soran käyttömahdollisuuksia lähinnä ns. yhdistelmäojituksessa, jonka rungon muodostaa harva tiiliputkiojaverkosto ja jossa soraa käytetään syvennettyjen avo-ojien pohjalla. Vesi johdetaan soraojista tiiliputkiojiin risteyskohtiin asetettujen siiviläputkien kautta. Useimmissa tapauksissa jää tiiliputkiojien kokonaismäärä noin puoleen tavallisen salaojituksen edellyttämästä ojamäärästä, joten soraojituksen edullisuus on lähinnä riippuvainen soraojien määrästä ja niiden tekokustannuksista. Soraojien syvyyden, soramäärän ja sen laadun sekä maalaji- ja kaltevuussuhteiden vaikutusten selvittämiseksi on aikomus perustaa eräitä salaojituskoealueita yksityistiloille lähinnä sellaisiin osiin maata, joissa tämän ojitustavan käytön laajenemiselle soran saannin kannalta on edellytyksiä.

M y y r ä o j i t u k s e n käyttömahdollisuuksia on katsottu olevan syytä edelleen tutkia myös nykyisen koetoiminnan yhteydessä, vaikkakin tästä ojitustavasta on eräiden 1920-luvulla saatujen kielteisten kokemusten johdosta Suomessa myöhemmin kokonaan luovuttu (3). Monissa muissa, kylläkin Suomea eteläisemmissä, maissa on myyräojitus sitävastoin osoittautunut tarkoitustaan vastaavaksi ja erityisen yleistä sen käyttö on Englannissa (20). Siitä on myös Ruotsissa saatu varsin myönteisiä kokemuksia, joiden perusteella on syytä otaksua, että tämä ojitustapa soveltuisi käytettäväksi etenkin lounais- ja etelä-Suomen lieju- ja urpasavialueilla ja ehkäpä laajemmassakin mitassa myös aitosavialueilla (4 ja 8).

Runkoverkostona myyräojituskokeissa on käytetty harvaa poikittaissuuntaista tiiliputkiojitusta, jossa imuojien etäisyys on $50-100 \mathrm{~m}$ ja syvyys $70-80 \mathrm{~cm}$ (kuva 5 ). Nämä ojat on täytetty miltei muokkauskerrokseen saakka soralla ja așetettu niihin riittävä määrä siiviläputkia, joiden kautta vesi myyräojista pääsee soran kautta tiiliputkisalaojiin. Myyräojat ajetaan jokaisen avo-ojan pohjalle ja maalajista riippuen lisäksi 1-3 myyräojaa kullekin saralle. Myyräojien syvyytenä on käytetty 50 - $60 \mathrm{~cm}$ ja myyräsukkulan läpimitta on ollut joko 3" tai 4"'.

Myyräojien etäisyyteen ja syvyyteen kohdistuvien tutkimusten lisäksi on tarkoitus selvittää miten ojien kunnossapysymisaika on riippuvainen maalajista, kaltevuussuhteista, roudasta ja muista mahdollisista seikoista. Lisäksi aiotaan erilaisilla savilla ja eri kosteustiloissa suorittaa vetovastusmittauksia edullisimman myyräojien ajoajan ja ajotavan selvittelyä varten. Alustavista kokeista mainittakoon, että esim. maatalouskoelaitoksella Tikkurilassa saatiin 7-tuntisena työpäivänä vedetyksi $15 \mathrm{~km}$ myyräreikää, jonka syvyys oli $50-55 \mathrm{~cm}$ ja läpimitta $10 \mathrm{~cm}$. Näin tuli yhdessä ainoassa päivässä ajetuksi n. 5 ha:n peltolohkolle myyräojat siten, että myyräreikien etäisyys toisistaan oli vain n. $3 \mathrm{~m}$.

Salaojien syvyyden selvittely. Matalampaan salaojitukseen siirtyminen on luonnollisesti omiaan pienentämään salaojien kaivukustannuksia. Maamäärän pienenemisen vuoksi vaikuttaa kaivukustannuksia alentavasti tällöin myös, että näin 


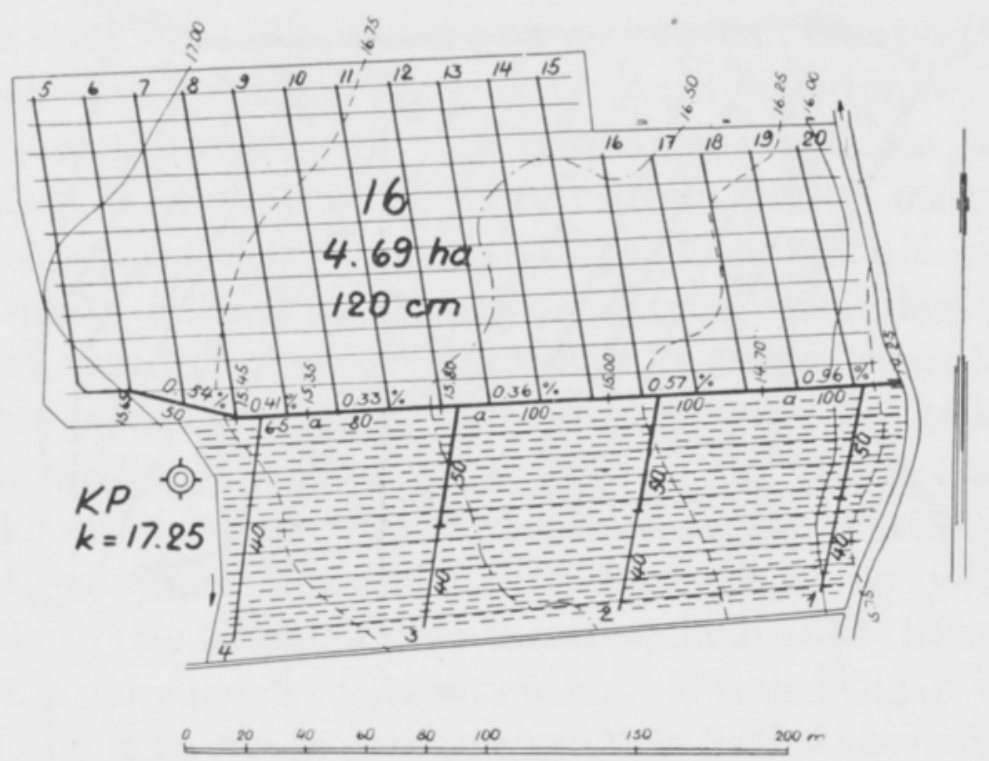

Kuva 5. Salaojituskoealue myyräojituksen käyttöedellytysten selvittelyä varten aitosavimaalla.

Figure 5. Experimental deep-drainage area for determining the requirements of mole drainage on heavy clay soil. Depth of mole drains $50 \mathrm{~cm}$. diameter of channel 4" and drain length about $65 \mathrm{~m}$. The water is directed from the mole channels via perforated pipes through a gravel layer, lying above them to the tiled mains. For comparison's sake the other half of the area is deep drained by means of tiles at intervals of $16 \mathrm{~m}$. and at a depth of $120 \mathrm{~cm}$.

vältytään käsittelemästä syvemmällä olevia maakerroksia, jotka usein ovat joko kaivuvaikeudeltaan huomattavan kovia, tai sitten niissä esiintyy työn suoritusta vaikeuttavaa juoksevuutta ja lakoilua. Niinpä esim. Ruotsissa käytettyjen syvyyksien hyväksyminen meillä merkitsisi lapiotöissä kaivukustannusten alenemista 30 - $60 \%$ :lla ja salaojituksen kokonaiskustannusten alenemista vastaavasti $10-$ 20 \%:lla (12). Mikäli kaivutyö suoritetaan koneellisesti käyttäen Suomessa nykyisin yleisimpiä, kaivupyörällä varustettuja, suuria salaojan kaivukoneita, jää ojasyvyydestä johtuva kustannusero muiden työn suoritukseen vaikuttavien seikkojen vuoksi kuitenkin varsin vähäiseksi. Tämän seikan merkitystä harkittaessa on otettava huomioon, että huomattava osa salaojien kaivutöistä maassamme joudutaan maalajisuhteiden vuoksi aina suorittamaan lapiotyönä. Nykyisin on koneellisen kaivutyön osuus varsin pieni, vain $20-30 \%$ koko määrästä. Suurimman säästön aiheuttanee matalampaan ojitukseen siirtyminen kuitenkin vähentämällä valtaojien perkauskustannuksia, sillä nykyisten syvyyksien käyttö johtaa tasaisilla viljelysalueilla usein jopa $2 \mathrm{~m}$ syvään valtaojitukseen (11).

Matalampaan salaojitukseen siirtymisen teknillisten edellytysten selvittelyssä on päähuomio kohdistettu maamme vanhimpiin tiiliputkisalaojituksiin. Suoritetun tiedustelun perusteella on tähän mennessä saatu selville 43 sellaista tilaa, joilla on tällaista 1800-luvun jälkipuoliskolla toteutettua salaojitusta pinta-alaltaan yhteensä yli 300 ha. Putket ovat pääasiallisesti kotimaista valmistetta, sillä maassamme oli jo v. 1863 kuusi tiiliputkitehdasta (1). Kun vanhoista salaojituksista on suurin osa nykyistä matalampaa, syvyyden ollessa keskimäärin vain $70-90 \mathrm{~cm}$, on 


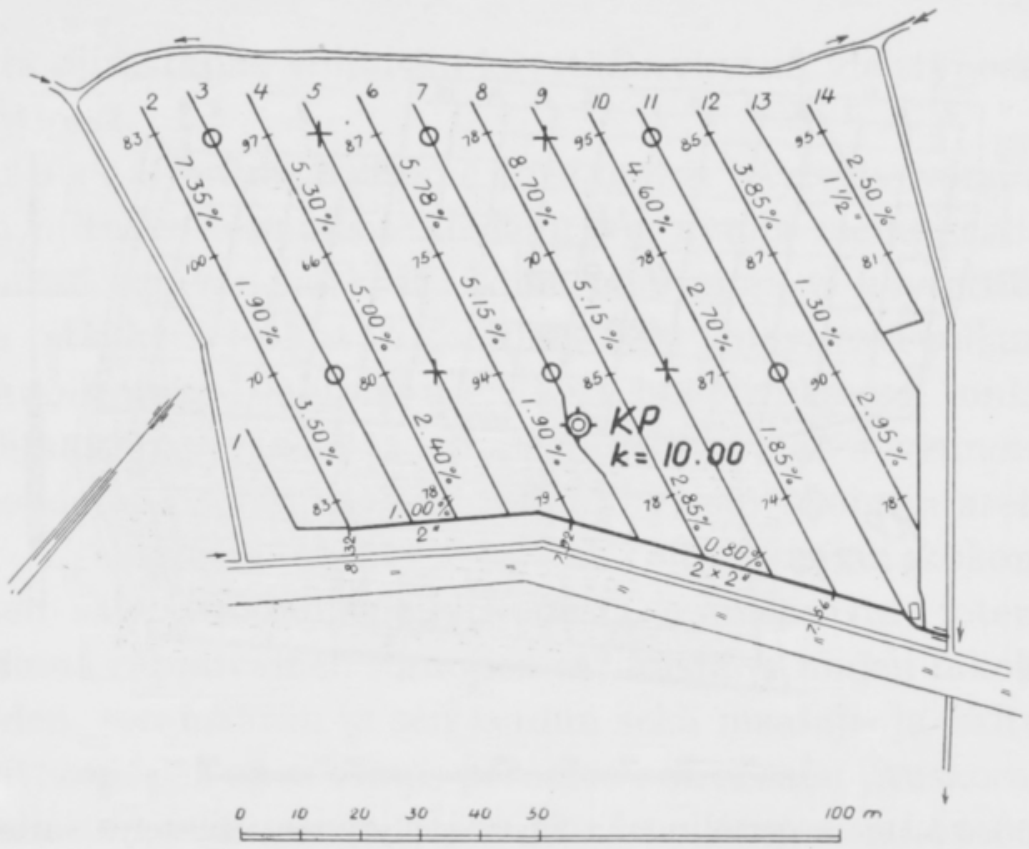

Kuva 6. Kartta eräästä v. 1874 toteutetusta tiiliputkiojituksesta ojansyvyys- ja putoussuhdemerkintöineen.

Putkisaumojen vedenläpäisymittauskohdat $=\mathrm{O}$

Täytemaan tiivistymismittauskohdat $\quad=+$

Figure 6. Map of a tile drainage carried out in 1874 with notes of the depths and the gradients. Points for the measurement of the water permeability of the tile joints $=\mathrm{O}$ Points for the measurement of the consolidation of the earth filling $=+$

katsottu tarkoituksenmukaiseksi mm. tutkia, missä määrin niissä ilmenee routavaurioita ja juuritukkeutumia.

Tällainen tutkimus suoritettiin keväällä $1952 \mathrm{~mm}$. Östersundomin kartanossa Sipoossa peltolohkolla, jonka salaojitus oli toteutettu jo v. 1874, joten ojituksen ikä oli tutkimusaikana 78 vuotta. Salaojituksesta ei ollut olemassa minkäänlaista karttaa, joten jokaisen ojan ja liitoskohdan paikka oli erikseen lapiota ja teräspuikkoa apuna käyttäen etsittävä ja kartoitettava (kuva 6).

Putkien kunnon toteamista varten otettiin joka toisesta imuojasta 20 metrin välimatkoin ylös 10 putkea. Imuojaputkien sisäläpimitta oli keskimäärin $34 \mathrm{~mm}$ eli vajaa $1 \frac{1}{2}$ tuumaa ja pituus n. $30 \mathrm{~cm}$. Kokoojaojassa oli käytetty 2"'n putkea ja sen alaosassa kahta tällaista rinnakkain. Putket olivat varsin tasalaatuisia ja hyviä, eikä niissä voitu todeta minkäänlaista rapautumista. Rikkoutuneita tai paikaltaan siirtyneitä putkia ei myöskään löytynyt yhtään kappaletta siitäkään huolimatta, että syvyys matalimmissa kohdissa oli alle $70 \mathrm{~cm}$. Putkien päällä ei ollut käytetty sora- tai muunlaista suojusta, vaan oli ne peitetty n. $7-8 \mathrm{~cm}: n$ vahvuisella kerroksella raakaa savea, minkä jälkeen oja oli täytetty siten, että muokkauskerroksen maa oli sekoittunut muuhun täytemaahan. Maalaji suurimmalla osalla aluetta oli tiivistä hiesusavea.

Putkitutkimuksen yhteydessä vaakittiin myös ojien putoussuhteet ja useimmissa tapauksissa oli putous ojien alaosissa huomattavasti pienempi kuin ylempänä. Tämän johdosta olikin yllättävää todeta, ettei putkissa yleensä ollut haitallisessa 
määrin lietettä ja ettei sitä siellä; missä putous oli pieni, esiintynyt enemmän kuin jyrkempiputouksellisissa kohdissa. Suoranaisia juuritukkeutumia ei esiintynyt lainkaan ja erillisiä juurisäikeitäkin oli vain muutamissa putkissa sekä syvissä että matalammissa ojissa. Liitoskohdat oli tehty osittain päältä- osittain sivultaliitoksina siten, että kokoojaputkeen oli hakattu tarpeellinen reikä ja imuojaputken pää sijoitettu tähän, minkä jälkeen liitoskohta oli peitetty tiiliputken palasilla. Tutkimuksen yhteydessä vaihdettiin kaikkiin liitoskohtiin nykyaikaiset liitosputket.

Putkisaumojen vedenläpäisykykymittauksia suoritettiin kaikkiaan kuudessa karttaan renkaalla merkityssä kohdassa (kuva 6). Tämän tutkimuksen tarkoituksena oli selvittää ovatko saumakohdat vuosikymmenien aikana syystä tai toisesta haitallisesti tiivistyneet, ja minkälainen niiden vedenläpäisykyky nykyään on. Mittausta varten paljastettiin 10 saumakohtaa varovaisesti ojakourua käyttäen. Putkien päälle levitettiin n. $2 \mathrm{~cm}: n$ vahvuudelta karkeata soraa. Mittauskohdan ylä- ja alapäähän tehtiin peltilevyä apuna käyttäen pato ja alapäähän lisäksi vesimäärämittausta varten tarvittava syvennys. Vettä varastotynnyristä kumiletkua myöten juoksutettaessa pidettiin se keskimmäisen putken kohdalla jatkuvasti samalla, joko 10 tai $15 \mathrm{~cm}: n$ korkeudella putken yläpinnasta lukien ja mitattiin alimmaisesta putkesta aikayksikössä virtaava vesimäärä. Suoritetuissa mittauksissa todettiin putkisaumojen vedenläpäisykyvyn olevan esim. $10 \mathrm{~cm}: n$ painekorkeutta käytettäessä keskim. vielä 4 kertaa suurempi kuin mitä nykyinen mitoitusperuste, 1 litra sekunnissa hehtaarilta, olisi edellyttänyt.

Täytemaan tiivistymismittauksia varten otettiin maanäytteitä neljästä eri kohdasta salaojaputkiston päältä, samoin kuin myös keskisaralta (kuva 6). Näytteiden ottosyvyydet olivat $30-45 \mathrm{~cm}$ ja $65-80 \mathrm{~cm}$ ja kultakin syvyydeltä otettiin kolme rinnakkaisnäytettä. Näytteenottolieriön sisäläpimitta oli $86 \mathrm{~mm}$ ja korkeus $150 \mathrm{~mm}$. Vedenläpäisykykymittauksissa määrättiin noin tunnin juoksutuksen jälkeen $23: n, 100: n$ ja 200:n \%:n putouksia käyttäen ns. näennäinen vedennopeus eli aikayksikössä läpäissyt vesimäärä jaettuna näytelieriön poikkipinta-alalla. Näiden mittausten mukaan oli tiiliputkien päällä oleva täytemaa säilyttänyt syvemmällä melkoisen huokoisuuden, mutta lähempänä pintaa, $30-45 \mathrm{~cm}$ :n syvyydellä, vuosikymmenien kuluessa tiivistynyt miltei vedenläpäisykyvyltään koskemattoman maan kaltaiseksi. Jatkotutkimusten avulla pyritään selvittämään, missä määrin täytemaan tiivistyminen on omiaan heikentämään vanhojen salaojitusten kuivatustehoa.

Kesällä 1952 suoritettiin edellä selostetunlainen tutkimus kaikkiaan kuudella sellaisella tilalla, jossa tiiliputkiojituksen ikä oli yli 70 vuotta. Putkia tarkastettiin kaikkiaan $525 \mathrm{kpl}$. Ojien syvyys oli vaihdellen $39-127 \mathrm{~cm}$. Putkista särkyi ylösotettaessa kokonaan $1 \mathrm{kpl} \mathrm{ja} \mathrm{osittain} 6 \mathrm{kpl}$., mutta olivat ne kaikki ojassa paikallaan ollessaan täysin toimintakykyisiä. Putket, jotka rikkoutuivat, eivät olleet ojitusten matalimmissa kohdissa, joten syynä niiden heikkouteen ei voine olla routa. Myös muissa suhteissa olivat tutkimustulokset em. tiloilla samansuuntaisia kuin Östersundomin kartanossa. Riittävän selvyyden saamiseksi on näitä tutkimuksia tarkoitus vuoden 1953 aikana edelleenkin jatkaa.

Matalampaan salaojitukseen siirtymisen vaikutusta on syytä tutkia myös taloudelliselta kannalta. Tätä 


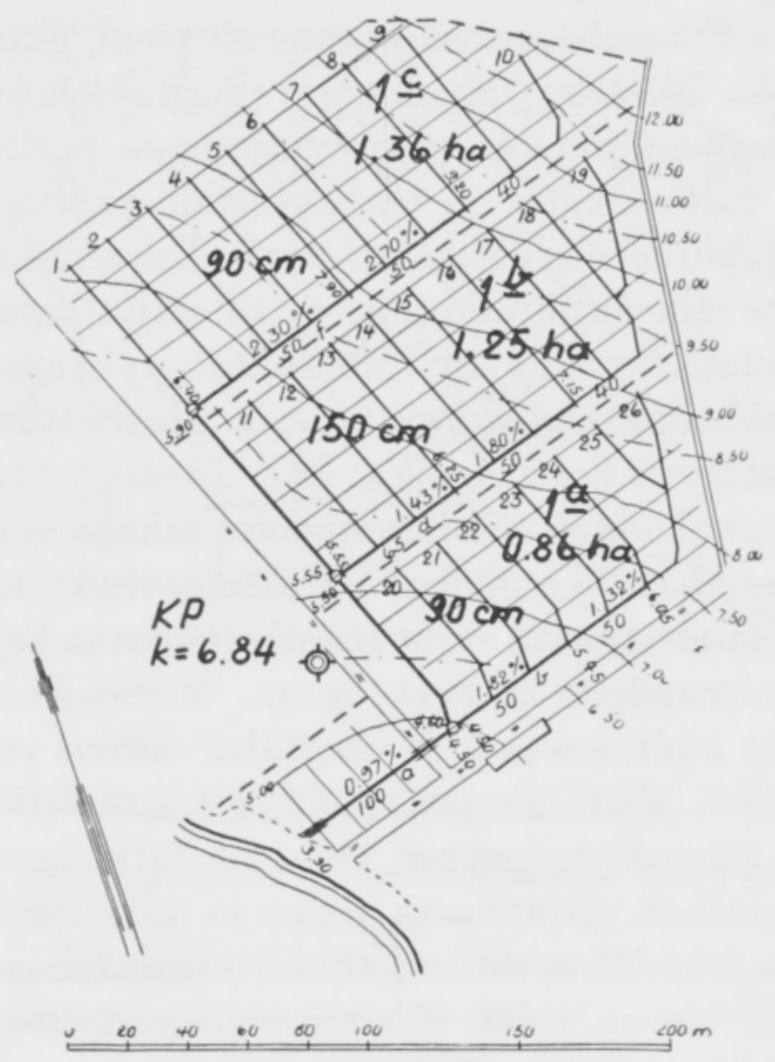

Kuva 7. Salaojituskoealue salaojien erilaisen syvyyden vaikutusten selvittelyä varten tiiviillä hiesusavimaalla.

Figure 7. Experimental deep-drainage area for determining the effects of different depths on heavy silt clay soil. The drain distance on the whole area is $16 \mathrm{~m}$. and the depths to be compared are 90 and $150 \mathrm{~cm}$.

tarkoitusta varten eri osiin maata perustettavilla koealueilla tullaan selvittämään mm. ojien syvyyden vaikutusta satotulokseen. Vertailusyvyyksiksi on valittu $60,90,120$ ja $150 \mathrm{~cm}$. Luvut tarkoittavat etäisyyttä ojan pohjasta maan pintaan mitattuna. Toiminnan vapaaehtoisuudesta johtuen ei yksityistiloja voida rasittaa riittävällä määrällä kerrannaiskokeita. Tämän johdosta on tyydyttävä yksinkertaisempiin ratkaisuihin ja monesti käytettävä vain kahta vertailusyvyyttä (kuva 7). Kerrannaisten puutteen aiheuttama koetulosten epäluotettavuus pyritään kumoamaan lisäämällä vastaavasti edellä selostetun tapaisten yksinkertaisten kokeiden lukumäärää.

Syvyyskokeita varten valittuja koealueita oli vuoden 1952 lopussa valmiiksi salaojitettuna yhteensä $34 \mathrm{kpl}$ käsittäen n. 210 hehtaaria.

Salaojien etäisyyden tutkiminen. Mikäli salaojien määrää pinta-alayksikköä kohden voidaan vähentää, aiheuttaa tämä lähes vastaavan kokonaiskustannusten alenemisen salaojitustöissä. Salaojien etäisyyden muutoksella onkin huomattavasti suurempi merkitys tässä suhteessa kuin syvyyden muutoksella. Meikäläisissä oloissa on kuivatustoiminnassa ennen kaikkea tärkeätä saada viljelykset keväisin lumen sulamisen jälkeen mahdollisimman nopeasti kuivumaan riittävän kantaviksi muokkausja kylvötöitä varten. Lähinnä peltolohkon viettävyydestä ja maalajista riippuen sekä sen asemasta kevättuuliin ja auringonvaloon nähden saatetaan eri tapauksissa 


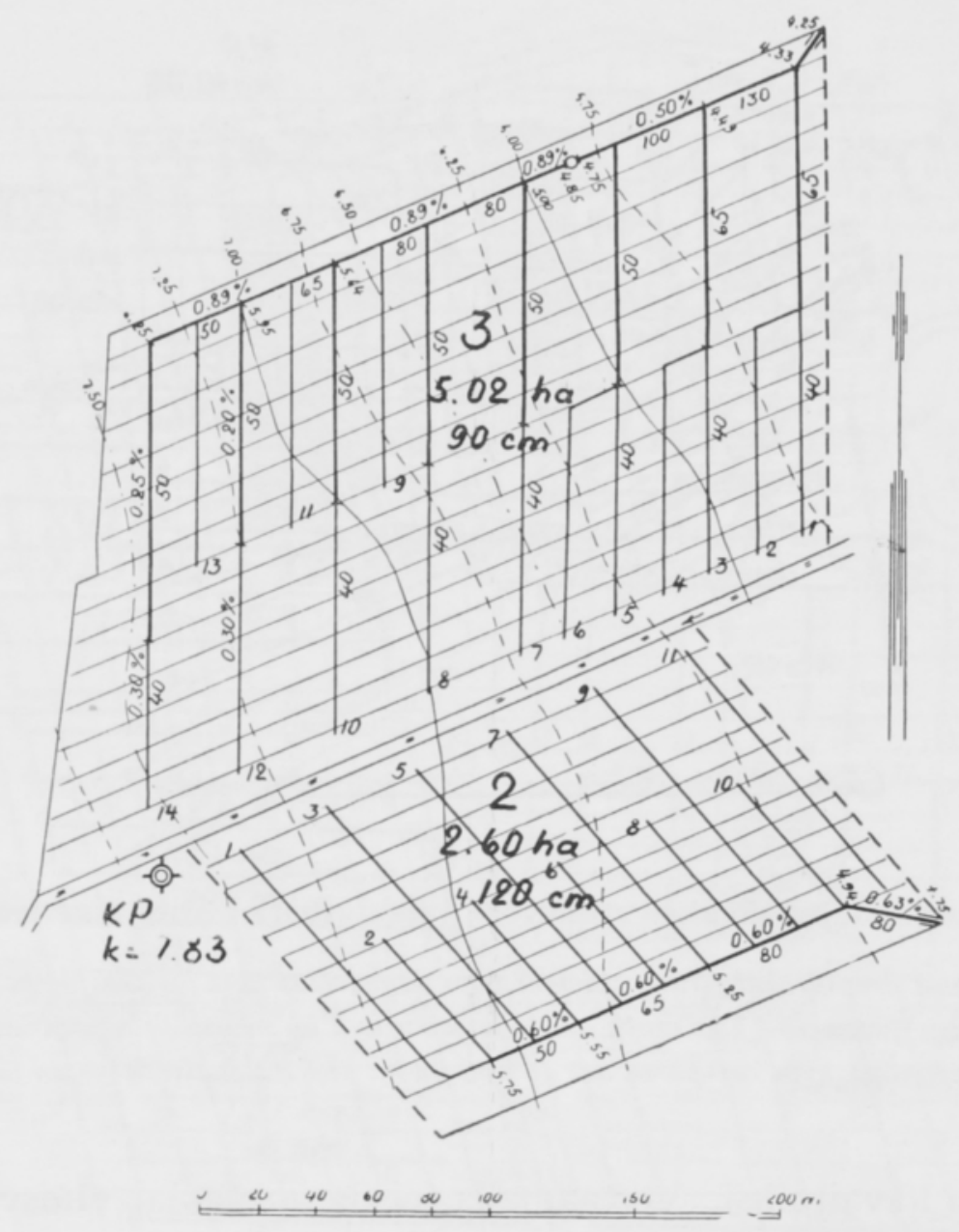

Kuva 8. Salaojituskoealue salaojien erilaisen etäisyyden selvittelyä varten aitosavimaalla.

Figure 8. Experimental deep-drainage area for determining the effects of different drain distances on heavy clay soil. In one part of the area the drains are $90 \mathrm{~cm}$. deep and in the other part $120 \mathrm{~cm}$. deep. The distances to be compared are 16 and $32 \mathrm{~cm}$. The crops are to be havvested in sections.

päästä toivottuun tulokseen hyvinkin erilaisia ojaetäisyyksiä käyttäen. Tämän johdosta on katsottu tarpeelliseksi nyt kysymyksessä olevan koetoiminnan yhteydessä perustaa eri osiin maata myös huomattava määrä salaojien etäisyyskokeita. Koejärjestelyssä on käytetty kahta eri tapaa. Yksinkertaisin ja yleisin muoto on se, että toinen puoli koealueesta salaojitetaan nykyistä ojaetäisyyttä käyttäen ja toisella puolella jätetään joka toinen salaoja toistaiseksi tekemättä, jolloin etäisyys saadaan kaksinkertaiseksi (kuva 8). Mikäli satoerot tällaisessa kokeessa ovat kovin suuria ja harvempi ojitus huomattavasti hidastaa kevätkuivumista, on ojitus myöhemmin helppo täydentää. Toinen etäisyyskoemuoto on pyritty sijoittamaan sellaisille tiloille, joilla käytetään leikkuupuimuria. Näissä kokeissa vuorotellaan nykyisin käytettyä ja siihen verrattuna kaksinkertaista ja osassa kokeita vieläkin leveämpää ojaetäisyyttä. Tällaista koejärjestelyä käytetään mm. Ruotsissa (5). Yksinkertaisin koe käsittää kolme kapeata ja kaksi näiden välissä olevaa leveää salaojaväliä (kuva 9). Sato on tarkoitus korjata leikkuupuimurilla salaojan suuntaisina kaistoina, joten sen muutokset salaojasta etäännyttäessä tulevat sekä tiheässä että harvem- 


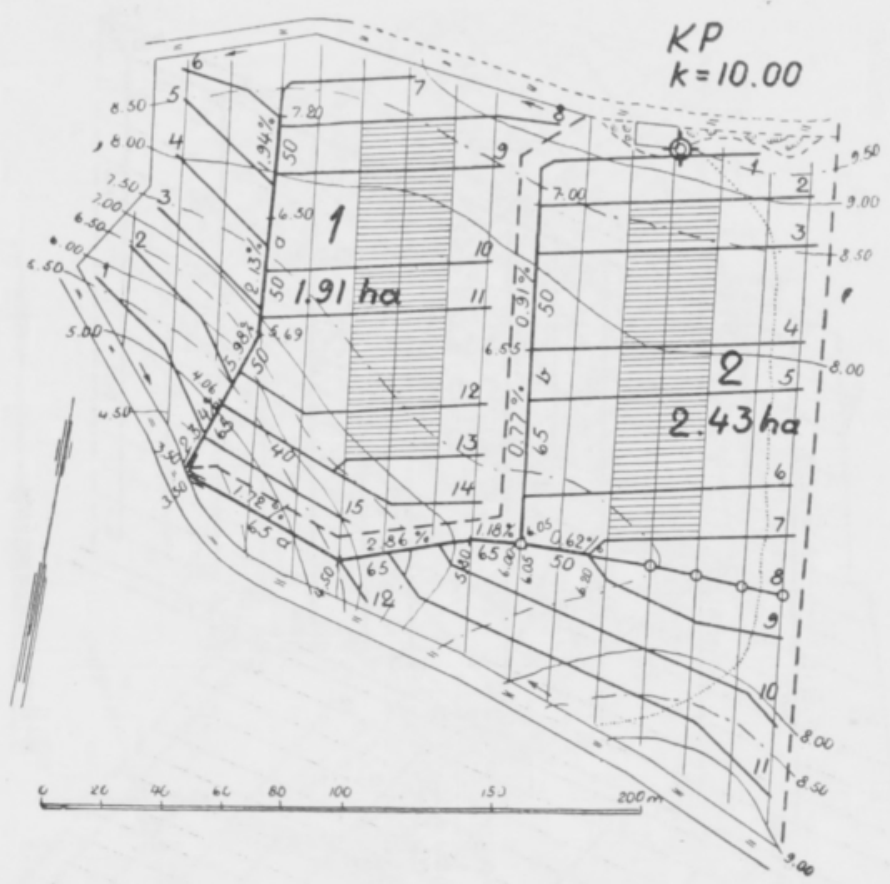

Kuva 9. Kaistakoe salaojien erilaisen etäisyyden vaikutusten selvittelyä varten aitosavimaalla.

Figure 9. Experimental deep-drainage area planned for heavy clay soil for the purpose of determining the effects of different drain distances. The crops are to be havested by means of a combine from strips parallel to the drains. The distances to be compared are 16 and $32 \mathrm{~m}$. and the drain depth on the whole area $120 \mathrm{~cm}$.

massa ojituksessa havaituiksi. Vertaamalla toisiinsa salaojan etäisyyden vaikutusta sadon raha-arvoon ja ojituksen vuotuiskustannuksiin saadaan selville mikä ojaetäisyys kunakin vuonna olisi ollut taloudellisesti edullisin. Lisäksi pyritään selvittämään ojaetäisyyden vaikutusta kevätkuivumiseen ja sen tasaisuuteen samoin kuin myös pinnan kantavuuteen koneitten käyttömahdollisuuksia silmällä pitäen.

Salaojien etäisyyskokeita oli vuoden 1952 lopussa valmiina 19 tilalla käsittäen kaikkiaan n. 114 hehtaaria.

Esimerkkinä varsinaisista salaojituskoekentistä, jotka ovat edellä selostettuja yksityistiloille perustettuja salaojituskoẻalueita monipuolisempia, esitettäköön lopuksi Maatalouskoelaitoksen ojituskoekenttä Tikkurilassa (kuva 10). Salaojien etäisyyskoe käsittää lohkot XVII ja XVIII. Salaojien syvyyden vaikutusten selvittämiseksi on tässä etäisyyskokeessa käytetty vuorotellen syvyyksiä 90 ja $120 \mathrm{~cm}$. Purkautumishavaintoja varten on neljä n. 1.5 ha:n suuruista lohkoa, XVI a, b, c ja d, salaojitettu eri syvyyksiä käyttäen. Koealueeseen kuuluu lisäksi täysin ojaton alue, XIII, jota viljellään vain vesivakoja käyttäen. Vertailua varten on lohko XIV avo-ojitettu. Eräiden myyräojituksen ja risuriukuojituksen toimintaan liittyvien kysymysten selvittelyä varten on varattu lohkot XII ja XV. Salaojituskoekenttä käsittää 22.54 ha ja on kokonaisuudessaan salaojitettu v. 1952. 


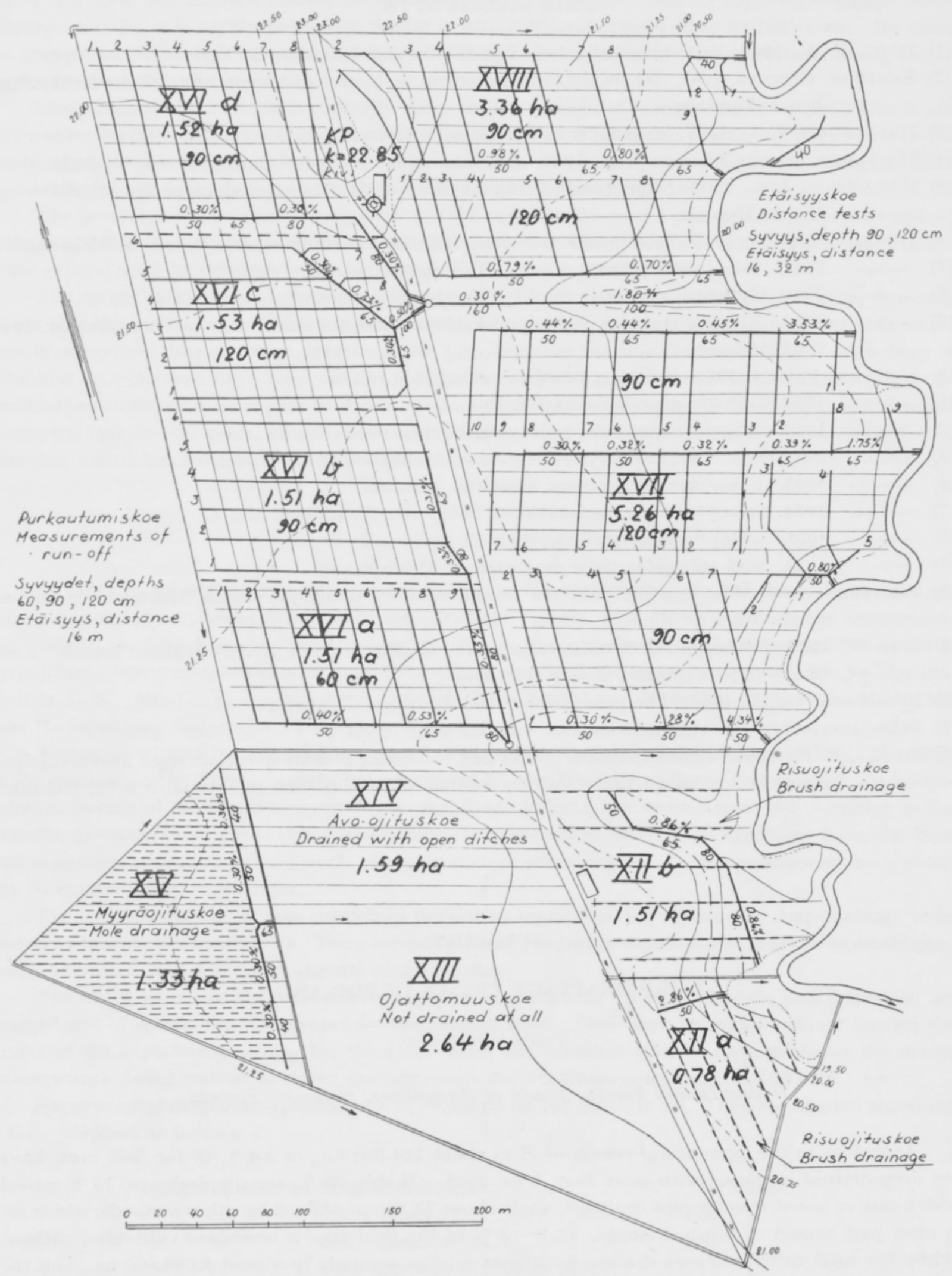

Kuva 10. Salaojituskoekenttä Maatalouskoelaitoksella Tikkurilassa.

Figure 10. Experimental drainage field at the Agricultural Research Centre, Tikkurila. 
KIR J ALLISUUTTA

(1) DAhL, F. A., 1863. Pelto-maan ojituksesta ja tiili-torvien tekemisestä. Turku.

(2) Eкströм, GunNar, 1947. Några dräneringsproblem ur hydrologisk synpunkt. Grundförbättring, N:o 1, Uppsala.

(3) Hallakorpi, I. A., 1927. Myyräojitus. Maatalous, 8, Helsinki.

(4) Hallgren, C. och Johansson, O., 1947. Om tubulering. Grundförbättring, N:o 3, Uppsala.

(5) HÅkAnsson, AUG., 1952. Några resultat från täckdikningsförsöksverksamheten. Grundförbättring, N:o 1, Uppsala.

(6) Juusela, Taneli, 1947. Salaojaputkiston mitoituksesta. Teknillinen Aikakauslehti, Helsinki.

(7) —— 1947. Salaojasyvyyskysymyksen selvittelyä. Ibid. 19.

(8) —— 1950. Myyräojituksesta ja sen käyttömahdollisuuksista Suomessa. Ibid. 22.

(9) —— 1953. Risujen, riukujen ja kivien käytöstä salaojituksessa. Maa- ja vesirakentaja, 1951 -52 , Helsinki.

(10) Kaitera, Pentti, 1951. Peltojen salaojituksesta. Ibid. 23.

(11) —— 1952. Peltojen salaojituksesta II. Ibid., 24.

(12) —— 1952. Salaojituskysymyksiä. Käytännön maamies, N:o 1.

(13) Keso, Lauri, 1932. Laidunviljelysten kuivatus. Helsinki.

(14) —— 1943. Salaojitus. Maamiehen käsikirja. Helsinki.

(15) —— 1944. Salaojituksen erikoisuuksista Suomessa. Maatalous, N:o 4 .

(16) —- 1951. Salaojitusmenetelmistä. Ibid. 23.

(17) —— 1952. Mitä salaojitus tulee maksamaan. Helsinki.

(18) Kotiano, Auvo, 1952. Suoviljelystemme sarkaleveydestä ja ojasyvyydestä. Maatalous ja koetoiminta VI.

(19) — — 1953. Suomaan salaojituksesta ja vertailua salaojituksen ja avo-ojituksen kesken. Koetoiminta ja käytäntö, N:o 2, Helsinki.

(20) Nicholson, H. H., 1946. The principles of field drainage. Gambridge.

(21) Salaojitusyhdistyksen vuosikertomukset vuosilta 1921-1951.

(22) Simola, E. F., 1936. Peltoviljelyskiertokokeiden tuloksista maatalouskoelaitoksen kasvinviljelysosastolla vv. 1914-1926. Valtion maatalouskoetoiminnan julkaisuja, N:o 78, Helsinki.

SUMMARY:

DEEP-DRAINAGE TRIALS IN FINLAND

Taneli JuUsela

Hydrotechnical bureau, Board of Agriculture, Helsinki, Finland

According to the agricultural census of 1950 about 124.000 ha., or $5,4 \%$ of the field area, have been deep-drained on farms with more than 2 ha. field. Of this, $50 \%$ are tile drainage, $15 \%$ nailed wooden case or bored wooden pipe drainage, while about $35 \%$ are drained by other methods, which for the most part consist of brush drainage. Only $10 \%$ of the field area is nowadays cultivated without ditches: the total cultivated area drained with open ditches amounts to almost 2.000 .000 ha., and the total length of the open ditches to at least $1.600 .000 \mathrm{~km}$. About 1.400 .000 ha. have been calculated to be in need of deep-drainage and also worth deep-draining.

The increasing use of machines in field cultivation has made it urgently necessary to determine the best way to eliminate the disadvantages caused by open ditches. If this work were to be carried out with the present deep-drainage methods, it would take at least 200 years at the present speed, and 
would cost over 100 milliard marks, calculated according to present prices. However desirable deepdrainage may be, it is hardly possible to realize it with sufficient speed and to its full extent. By using the present methods such an undertaking would exceed the capacity of our agriculture, owing to the great expense involved.

Deep-drainage in Finland is generally more expensive than in many other countries. This is not only due to the differences in soil and climate or the high level of prices and wages, but partly also to the special character of our deep-drainage. Thus we use a $30-50 \mathrm{~cm}$. deeper drainage here in Finland than in Sweden, yet the drain distances are almost the same in the two countries.

The present methods used in deep-drainage are based partly on the practice that prevailed abroad in the nineteen-twenties, and partly on the belief of the farmers themselves and the deep-drainage experts in the general need for drainage of the cultivated land.

The recent trials have unfortunately been limited and scattered. Their results have, however, shown that the method of drainage has affected the crop yield to a surprisingly small extent both where open drainage and deep-drainage are concerned, provided that the side and main ditches have been in order and waterfurrows have been used to a sufficient extent. That the need for drainage seems to be smaller than expected may in part be due to the fact that the ploughing depth has been almost doubled during the last $20-30$ years, and that the tilling has become more efficient than before, owing to the increased use of tractor-drawn tillage implements.

\section{The scope of the trials}

In order to solve the drainage problem finally, in the early spring of 1951 the Ministry of Agriculture appointed a special committee of deep-drainage experts, to draw up a plan of the experiments and trials to be carried out all over the country. Mr. A. H. Schroderus, chief engineer at the Board of Agriculture, was appointed chairman of the committee, which otherwise consists of Mr. Veikko Ihamuotila, B. Sc., Dr. Taneli Juusela, Prof. Pentti Kaitera, Prof. Lauri Keso, Mr. H. Korpela, M. A., Mr. Eino H. Seppänen, engineer and Prof. Otto Valle.

A general scheme for the trials was confirmed by the Ministry of Agriculture onMay 24, 1951. At the same time Dr. Taneli Juusela was appointed by the Ministry to direct this work at the hydrotechnical bureau of the Board of Agriculture. Mr. Erkki Pälikkö has worked from the beginning as the agricultural expert in charge of the investigations. In case of need, students of agronomy have also been used as summer assistants in field work. In tasks such as surveying etc., it has continuously been necessary to employ additional labour.

The main part of the scheme consists of the setting up of experiment fields for deep-drainage to be started at four state-owned farms. These are completed by separate experimental areas to be established mostly at private farms in different parts of the country.

The expenses involved by the surveying, planning, drawing up of documents, and inspection are financed out of special founds granted for the investigation. Thus these expenses will not burden the owners of the experiment farms. On the other hand, the farmer himself is responsible for the actual drainage work, being granted however, the customary deep-drainage compensation and loan.

Experimental deep-drainage areas are to be set up on 143 farms in all. They are divided according to their purposes as follows:

\begin{tabular}{|c|c|c|c|c|}
\hline Experiments & on & need of drainage $\ldots \ldots \ldots \ldots \ldots$ & 10 & farms \\
\hline n & $"$ & drain depth $\ldots \ldots \ldots \ldots \ldots \ldots$ & 40 & $"$ \\
\hline " & $"$ & drain distance $\ldots \ldots \ldots \ldots \ldots \ldots \ldots$ & 80 & " \\
\hline$"$ & $"$ & mole drainage $\ldots \ldots \ldots \ldots \ldots \ldots$ & 10 & " \\
\hline ) & " & gravel drainage $\ldots \ldots \ldots \ldots \ldots \ldots$ & 3 & " \\
\hline
\end{tabular}

Grants for the basic phase of the trials have been obtained from the Ministry of Agriculture out of funds intended for the promotion of agricultural production and for levelling the costs of same. The annual grants have been as follows: 


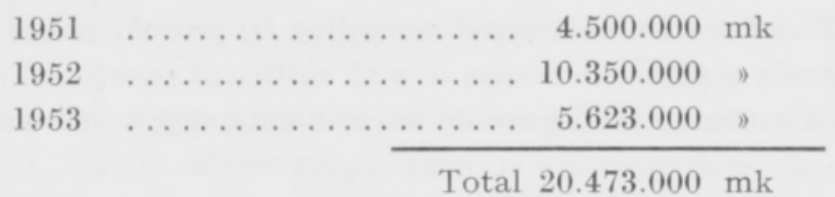

An attempt is being made to have the foundation work of the experimental deep-drainage areas and fields ready within the year 1953. The sums needed annually for the care of the experiment areas and for the treatment of the data obtained are included in the annual budgets of the hydrotechnical bureau of the Department of Agriculture.

\section{The purpose of the trials}

The aim of the drainage trials is to discover and develop methods, better both in terms of ultimate yields and of costs, for use in different circumstances. On the whole, the problem is not only one of deepdrainage. The purpose of the experimental deep-drainage work is to find out when and what kind of deep-drainage is needed and to what extent the fields can be cultivated either entirely without drainage or by using open ditches at greater distances than are used at present.

Investigations regarding different drainage methods. When trying to discover more profitable drainage methods than the present ones notice has been taken of the fact that about $\mathbf{4 4 . 0 0 0}$ ha. or $35 \%$ of the deep-drained field area has been drained by the famers themselves, using their own materials. In the investigation carried out on about 7.300 ha. of fields thus drained, about $80 \%$ of them werse found to be brush drained. Stone drainage amounted to $15 \%$ and gravel drainage and drainage carried out with various other methods to $5 \%$ of the area investigated.

Of the brush drainage, $74 \%$ was in good condition, $22 \%$ satisfactory and only $4 \%$ poor, in spite of the fact that about a quarter of the drains were over 30 years old. Consequently, carefully done brush drai nage remains active for an average of at least 30 years. The expences of brush drainage are in general less than half those of tile drainage, provided that no price is counted for the timber (about 5 cu.m. needed for 100 metres of drain). The use of this kind of drainage can still be recommended as a solution preceding deep-drainage on small farms where home labour is easily obtainable.

As far as stone drainage is concerned, the conclusion has been reached that there will not be much chance of utilizing this method, owine to the great amount of work involved.

Gravel drainage has so far been used to quite a small extent in this country, but it is evident that expenses could be cut down by using this method in regions where gravel of suitable particle size is available in great quantities and the transport distances are not too long. For the purpose of ascertaining the effects of the depth of the drains, the amount and quality of the gravel, the effects of the soil, and the declivity, a few experimental deep-drainage areas will be set up on private farms, situated mostly in parts of the country where this method may find general application on account of the availability of gravel.

On the basis of the experiences lately gained in Sweden of mole drainage it is to be supposed that this kind of drainage would be suitable especially on the mud and mud clay areas of Southwest and South Finland, and perhaps on a larger scale also on the heavy clay areas. Besides the investigations regarding the distances and depths of mole drains, the purpose of the trials is to discover the relation between of the durability of the drains and the soil, declivity, frost and other possible factors.

Investigations regarding drain depth. A change over to a shallower deep-drainage would help to reduce the expenses of digging the deep-drains and the main ditches. When working out the technical requirements for such a measure, a study has been made of the oldest tile drainages in this country. The bulk of these deep-drainages are over 70 years old and are shallower than the present ones, with an average depth of only $70-90 \mathrm{~cm}$. It is felt that it will be very much helpful to find out, amongst other things, to what extent frost damage and root stoppages are occurring in them.

Besides the technical requirements involved in a change over to a shallower deep-drainage system, the effects of such a measure from an economic point of view have to be investigated. For this purpose the effect of drain depth on the crop yield will, amongst other things, be studied on the experiment areas which have been set up in different parts of the country. $60,90,120$ and $150 \mathrm{~cm}$. are the depths that 
have been chosen for comparison. Owing to the voluntary nature of the trials private farms cannot be burdened with a sufficient number of simultaneous experiments. The consequent unreliability of the experimental results is to be eliminated by increasing the number of the experiment farms correspondingly.

Investigations regarding drain distance. Where the number of drains per areal unit can be decreased, this will cause a nearly corresponding reduction in the total expenses on the deep-drainage work. Thus a change in the drain distance has considerably greater importance in this respect than a change in the depth. Consequently it is considered necessary, in connection with the trials in question, to set up, in addition, a considerable number of experimental areas to ascertain the optimum drain distance in different parts of the country. Two different methods are included in the scheme. The simplest and most general is the method of deep-draining one half of the experimental area by using the present drain distance, while on the other half every other drain is omitted, the istance being thus doubled. The other kind of distance trial is to be tried on farms where a combine is used. In these experiments the present distance, a double one and in some experiments an even broader distance are used alternately. The crops are harvested with the combine from strips parallel to the deep-drains. Consequently the changes in the crops are noticed when drawing farther away from the drain both where the drains are frequent and less frequent. Furthermore attempts are to be made to ascertain the effect of drain distance on the spring drying and its evenness as well as on the capacity of the surface to carry machines. 